\title{
KAMPANYE INTRODUKSI KEGIATAN INTERNASIONAL COASTAL CLEAN-UP BAGI KONSERVASI HABITAT BIOTA LAUT SECARA SUISTAINABLE KAWASAN KONSERVASI MANGROVE BEKANTAN KOTA TARAKAN
}

\author{
Jimmy Cahyadi'); Gazali Salim²); Arif Fadlullah ${ }^{3)}$; M. Azmin'2) ; Putri Rahmadani'); \\ M. Nur Ikhsan ${ }^{1)}$; Sri Irmawati $\mathbf{R}^{1)}$ \\ 1) Jurusan Akuakultur Fakultas Perikanan Dan Ilmu Kelautan dan \\ 2) Jurusan Manajemen Sumberdaya Perairan Fakultas Perikanan Dan Ilmu Kelautan \\ 3) Jurusan Teknik Elektro Fakultas Teknik \\ Universitas Borneo Tarakan . Jalan Amal Lama Kota Tarakan Provinsi Kalimantan Utara \\ Email ; jim.borneo@gmail.com / axza_oke@yahoo.com. HP.081347288070
}

\begin{abstract}
ABSTRAK
KKMB (kawasan konservasi mangrove bekantan) merupakan daerah yang unik karena terletak ditengah kota berada dekat pertokoan Mall Gusher, pasar tardisional dan kawasan industri perikanan sehingga kawasan ini berdampak terhadap kerusakan habitat biota perairan berada di Kota Tarakan Provinsi Kalimantan Utara. Kegiatan kampanye coastal clean-up merupakan kegiatan masyarakat dunia internasional yang bertujuan untuk menggalakkan kebersihan wilayah ekosistem bagi keberlangsungan biota perairan laut dalam mempertahankan spesies agar tidak endemic atau punah dengan perlindungan secara suistainable di KKMB Kota Tarakan. Kegiatan coastal clean-up di KKMB kota Tarakan didapatkan 3 jenis sampah yaitu sampah dari wisatawan sebesar $18 \mathrm{~kg}$ dengan persentase 5,5\%, sampah alam sebesar $79 \mathrm{~kg}$ dengan persentase sebesar $24,2 \%$ dan sampah dari buangan masyarakat sebesar 229,4 kg dengan persentase sebesar 70,28\%. Kegiatan coastal clean-up untuk memberikan kesadaran dan kepedulian terhadap kelestarian ekosistem biota laut dengan di ikuti oleh peserta terbanyak berasal dari Bapak/Pria dewasa sebesar $40 \%$, di ikuti oleh peserta wanita remaja sebesar 24\%, serta pria remaja sebesar $16 \%$, Wanita / Ibu dewasa sebesar $11 \%$ dan peserta sedikit adalah anak-anak sekitar $9 \%$.
\end{abstract}

\section{Kata kunci : Coastal Clean-Up ; Introduksi ; Konservasi ; KKMB ; Kota Tarakan}

\begin{abstract}
KKMB (the proboscis monkey mangrove conservation area) is a unique area because it is located in the middle of the city, near Gusher Mall shops, traditional markets and fisheries industrial areas so that this area has an impact on the damage to the habitat of aquatic biota in Tarakan City, North Kalimantan Province. The coastal clean-up campaign is an activity of the international community which aims to promote cleanliness of the ecosystem area for the sustainability of marine biota in maintaining species so that they are not endemic or extinct with sufficient protection in the KKMB of Tarakan City. The coastal clean-up activity at KKMB Tarakan City obtained 3 types of waste, namely waste from tourists of $18 \mathrm{~kg}$ with a percentage of $5.5 \%$, natural waste of $79 \mathrm{~kg}$ with a percentage of $24.2 \%$ and waste from community waste of $229.4 \mathrm{~kg}$ with percentage of $70.28 \%$. Coastal clean-up activities to provide awareness and concern for the preservation of the marine biota ecosystem by being followed by the most participants coming from male / adult men by $40 \%$, followed by teenage female participants by $24 \%$, and teenage males by $16 \%$, women / Adult mothers were $11 \%$ and children were slightly participants around $9 \%$.
\end{abstract}

Keywords: Coastal Clean-Up; Introductions; Conservation; KKMB; Tarakan City 
$\underline{\text { Kampanye Introduksi Kegiatan Internasional Coastal Clean-Up..............(Jimmy Cahyadi dkk) }}$

\section{PENDAHULUAN}

Daerah Kawasan Konservasi Mangrove Bekantan (KKMB) mempunyai luas lahan sebesar $23 \mathrm{Ha}(14 \mathrm{Ha}+9 \mathrm{Ha})$ dan merupakan daerah yang unik, dimana daerah tersebut merupakan daerah konservasi bagi biota akuatik dan teresterial. Daerah ini merupakan daerah yang terletak ditengah kota yang terletak antara supermarket, pasar dan kawasan industri perikanan sehingga kawasan ini mendapat dampak yang sangat besar terhadap perlindungan ikan.

Kawasan KKMB merupakan kawasan konservasi yang berada di bawah pengawasan dan perlindungan dinas pariwisata sehingga kawasan tersebut merupakan salah satu destinasi wisata lokal dan mancanegara, namun demikian keindahan lokasi KKMB dicemari dengan banyaknya sampah yang berasal dari kawasan sekitar lokasi KKMB dan wilayah pesisir Kota Tarakan. Kawasan tersebut merupakan daerah yang memiliki energi sampah terbesar dikarenakan banyak sampah yang tidak dapat tereduksi dan terakumulasi ke dalam sedimen sehingga sampah tersebut menyebabkan tertimbun semakin banyak dan tertumpuk. Ironisnya bersebelahan batas lahan Lintang Utara area KKMB dibangun pasar tradisional dan pertokoan Mall Gusher sejak Tahun 2001.

Kondisi ini menambah beban sampah dan cemaran lainnya masuk kawasan KKMB. Mitra sasaran masyarakat pada kawasan KKMB adalah masyarakat yang tidak produktif secara ekonomi, sosial dan budaya. Mitra masyarakat tersebut terdiri dari kelompok ibu-ibu rumah tangga, kelompok anak-anak jalanan, dan para suami yang didominasi nelayan, pedagang setempat, pasar lokal dan pertukangan yang secara administrasi terdaftar pada penduduk Rukun Tetanga 2 (RT.2) kelurahan Karang Rejo Pantai Kecamatan Tarakan Barat Kota Tarakan Provinsi Kalimantan Utara.
Hal ini disebabkan karena banyaknya kurang kepedulian masyarakat akan kesadaran terhadap limbah sampah rumah tangga yang langsung di buang ke laut. Banyak masyarakat beranggapan bahwa apabila sampah yang telah di buang ke laut maka sampah tersebut akan lenyap tertelan arus dan ombak sehingga sampah tersebut akan hilang, namun demikian hal ini tidak seusai dengan hasil pengamatan ilmu pengetahan bahwa apabila sampah yang terbawa oleh arus laut yang tidak dapat terakumulasi ke dalam sedimen atau air maka sampah tersebut akan terbawa arus dan dalam beberapa tahun akan kembali lagi ke daerah tersebut.

Observasi yang telah dilakukan sebagian besar bahan pencemar seperti sampah (baik organik maupun anorganik) yang sering ditemukan di KKMB berasal dari wisatawan, limbah rumah tangga dan limbah pabrik yang hanyut terbawa arus dari badan perairan hingga wilayah pesisir pantai. Tingginya jumlah bahan pencemar seperti sampah di wilayah pesisir pantai sejalan dengan penelitian Handaka et al (2007), yang menyatakan bahwa sekitar 65\% bahan pencemar seperti sampah berada di wilayah pesisir Pantai Pameungpeuk di Kabupaten Garut berasal dari wisatawan dan limbah rumah tangga. Pencemaran lingkungan yang disebabkan oleh sampah atau bahan pencemar lain di wilayah pesisir akan berdampak pada organisme-organisme yang hidup di daerah wilayah pesisir pantai. Sebagai contoh, tingginya volume bahan pencemar seperti sampah atau pencemar lainnya dapat membunuh fitoplankton, zooplankton dan makrozoobentos di badan perairan sehingga produktivitas primer dan kualitas air menurun.

Menurut Awaluddin (2007), kegiatan bersih-bersih pantai (Coastal Clean-Up) ini sejalan dengan kampanye yang dilakukan oleh masyarakat internasional dalam menjaga wilayah pesisir pantai yang di gagas oleh Ocean Concervacy. Ocean Concervacy 
rutin melakukan standarisasi bahan pencemar yang sering ditemukan di wlayah pesisir pantai dan melakukan analisis terhadap hasil Coastal Clean-Up.

$$
\text { Menindaklanjuti program }
$$

International Ocean Concervacy, maka program Coastal Clean-Up perlu diadakan secara rutin di wilayah KKMB. Selain mendukung program pemerintah tentang konservasi wilayah pesisir dan program Ocean Concevacy tentang International Coastal Clean-Up, kegiatan Coastal CleanUp diharapkan mampu memotivasi masyarakat lokal dan para wisatawan agar menumbuhkan pengetahuan, kesadaran dan kepedulian yang secara bersama-sama menjaga ekosistem serta lebih pintar dalam memanfaatkan potensi ekowisata di wilayah KKMB di Kota Tarakan.

Kegiatan Coastal Clean-up yang sudah di lakukan adalah program pengabdian kepada masyarakat melalui pendanaan Universitas Borneo Tarakan yang telah dilakukan di kawasan Pantai Amal Lama Kota Tarakan oleh Salim Dan Febrinaldy (2016) melalui konsep Introduksi Program Coastal Clean-Up di Pantai Amal Kecamatan Tarakan Timur Kota Tarakan dan diperoleh hasil 4 (empat) jenis sampah yang di pisahkan yaitu sebanyak $303 \mathrm{~kg}$ yaitu didapatkan $18,3 \%$ sampah dari warga/masyarakat, 30,8\% sampah dari alam, $22,8 \%$ sampah dari wisatawan dan $28,1 \%$ sampah berasal dari usaha budidaya rumput laut Cahyadi dan Salim (2017), namun demkian kegiatan pengabdian Coastal Clean-Up di daerah Kawasan Konservasi Mangrove dan Bekantan masih jarang dilakukan. Tujuan kegiatan ini adalah untuk memberikan informasi dan pengetahuan mengenai pentingnya kegiatan internasional coastal cleanup bagi konservasi biota laut secara berkelanjutan di KKMB Kota Tarakan.

\section{METODE PENELITIAN}

\section{A. Bersih Pantai (Coastal Clean-Up)}

Kegiatan bersih pantai (Coastal Clean-Up) merupakan bagian dari upaya masyarakat internasional untuk peduli terhadap kebersihan wilayah lingkungan pesisir. Di kalangan internasional kegiatan Coastal Clean-Up melibatkan para relawan untuk melakukan kegiatan bersih pantai dengan metode survai, biasanya dilakukan dalam periode yang bersamaan atau serentak (Awaluddin, 2011). Masyarakat dunia mengenal kegiatan bersih pantai sebagai International Coastal Clean-Up (ICC) yang dilakukan secara serentak dan rutin setiap tahunnya di berbagai pesisir pantai di seluruh dunia.

ICC merupakan konsep kegiatan yang efektif untuk meningkatkan kesadaran masyarakat terhadap pencemaran pesisir pantai melalui pengalaman langsung survai dan mengambil sampah secara langsung (Ohkura dan Kojima, 2007). Berdasarkan Ohkura dan Kojima (2007), kegiatan tersebut dapat memberikan tantangan dan pengetahuan para peserta akan beberapa hal berikut :

- Sumber pencemaran pesisir pantai berasal dari sampah yang dihasilkan dari kegiatan masyarakat sehari-hari yang dibuang melalui sungai atau saluran lainnya.

- Setiap orang menghasilkan sampah yang mudah terlihat dan sudah dianggap maklum.

- Solusi yang terbaik adalah mengembangkan komunitas masyarakat yang peduli dan handal untuk menanggulangi pencemaran wilayah pesisir serta mengembangkan masyarakat untuk memiliki orientasi daur ulang.

Pelaksanaan kegiatan ini akan dilakukan menurut Awaluddin (2011) yang telah dilaksanakan di Pantai Sindangkerta, Kecamatan Cipatujah, Kabupaten Tasikmalaya, namun akan disesuaikan dengan kondisi eksisting di lokasi kegiatan 
$\underline{\text { Kampanye Introduksi Kegiatan Internasional Coastal Clean-Up..............(Jimmy Cahyadi dkk) }}$

KKMB. Ada beberapa hal utama yang harus menjadi perhatian dalam kegiatan-kegiatan bersih pantai (Coastal Clean-Up) KKMB ini,yakni :

1. Sebelum Kegiatan

- Koordinator kegiatan survai daerah yang tepat untuk dijadikan lokasi kegiatan ICC.

- Memperhatikan bahan-bahan logistik yang akan diperlukan dalam pelaksanaan kegiatan seperti: sarung tangan, plastik sampah, ATK dll.

Melakukan kontak dengan SKPD/Pemerintah Kota Tarakan untuk penanganan sementara dan akhir hasil sampah yang dikumpulkan.

- Memperhatikan barang-barang yang dapat di daur ulang, seperti kertas, plastik, kaca.

- Merencanakan penanganan untuk bahanbahan berbahaya, seperti lateks, jarum suntik dan tampon agar aman dari jangkauan anak-anak.

- Menyiapkan alat timbangan untuk mengukur berat sampah yang dihasilkan.

- Menyiapkan alat pertolongan pertama pada kecelakaan (P3K) di lokasi kegiatan.

- Memastikan para peserta mengetahui apa yang harus dilakukan bila menemukan hewan-hewan yang terjerat jaring.

- Melakukan simulasi atau penjelasan tentang teknis kegiatan kepada para peserta, serta menunjukkan cara mengisi form ICC data card.

- Melakukan pembagian kelompok.

2. Selama Kegiatan

- Menyiapkan tempat-tempat cek-point untuk para peserta, termasuk semua kebutuhan logistik yang diperlukan, termasuk berikan ICC data card untuk diisi selama kegiatan.

- Menyiapkan zonasi atau area yang harus dibersihkan. Setiap koordinator kelompok harus mengetahui lokasi tersebut.
- Menyampaikan kepada peserta untuk mengembalikan ICC data card setelah kegiatan berakhir.

- Melakukan pengambilan sampah seperti yang tercantum dalam ICC data card.

- Memberikan apresiasi terhadap para peserta dalam berbagai bentuk, seperti stiker/kaos.

3. Setelah Kegiatan

- Mengembalikan ICC data card kepada kooordinator untuk kemudian dilakukan analisis.

- Memberikan apresiasi terhadap para peserta dapat berupa kartu ucapan terima kasih, sertifikat dan atau yang sejenis lainnya.

\section{B. Pendekatan Kemitraan Masyarakat}

Undang-undang Nomor 6 tahun 2014 tentang Desa, dijelaskan bahwa Pemerintah Desa dan masyarakat desa bersama-sama membangun dengan semangat gotong royong dalam rangka pemanfaatan sumber daya alam demi tercapainya peningkatan kesejahteraan masyarakat desa serta kualitas hidupnya melalui pemanfaatan sumber daya alam dan lingkungan secara berkelanjutan. Upaya tersebut dimulai sejak perencanaan, pelaksanaan, hingga monitoring dan evaluasinya dengan pendekatan dan metode yang tepat. Salah satu cara yang cukup relevan untuk mengkaji kondisi lingkungan pedesaan adalah dengan penerapan pendekatan Participatory Rural Appraisal (PRA), dengan harapan akan tercipta suasana kerja yang kondusif, kolaburatif, adaptif dan partisipatif dalam proses perencanaan pembangunan dan pengelolaan sumber daya yang ada khususnya di wilayah pedesaan. PRA bisa dikatakan sebagai pendekatan, metode atau teknik, karena di dalamnya memang terdapat unsur-unsur tersebut. Di dalamnya terdapat beberapa teknik-teknik identifikasi, pengukuran dan pelibatan partisipatif masyarakat. 


\section{HASIL DAN PEMBAHASAN}

\section{A. Hasil Pengabdian kepada Masyarakat di KKMB Kota Tarakan}

Hasil pengabdian kepada masyarakat yang telah di laksanakan selama tiga hari dengan persiapan selama kurang lebih 4 bulan dimana kegiatan pengabdian kepada masyarakat di fokuskan di daerah Kawasan Konservasi Wisata Mangrove dan Bekantan (KKMB) Kota Tarakan.

Kegiatan pengabdian kepada masyarakat di laksanakan di daerah konservasi mangrove dan bekantan (KKMB) Kota Tarakan dilaksanakan di karenakan daerah tersebut merupakan daerah dimana daerah tersebut merupakan daerah yang menjadikan salah satu destinasi bagi para wisatawan local ataupun mancanegara yang di jadikan salah satu icon wisata di Kota Tarakan, selain itu pula di KKMB tersebut berdasarkan Tata Ruang Wilayah Kota Tarakan, juga memiliki satu kawasan yang mendukung antara kegiatan wisatawan dan kegiatan konservasi selama kawasan konservasi tersebut tidak dalam kategori kawasan yang telah rusak.

KKMB masuk kategori kawasan yang masih bisa layak untuk dapat di kunjungi oleh wisatawan di karenakan kawasan tersebut merupakan kawasan bagi biota endemic namun biota endemic tersebut tidak terganggu oleh kegiatan wisatawan. Biota endemic di kawasan KKMB adalah biota terrestrial berupa bekantan, namun demikian untuk bioata di kawasan aquatic tidak ada kategori biota yang endemic. Pada kawasan KKMB kota Tarakan merupakan kawasan konservasi baik bagi biota terrestrial ataupun biota aquatic. Habitat biota aquatic yang berada di KKMB tersebut cukup beraneka ragam yaitu ikan tempakul, kepiting uca Sp, kerang kapah (Geloina coaxans), kepiting bakau (Scylla serrate), kepiting batu, ikan, kerang kuku, gastropoda, bivalvia, udang, dan lain sebagainya.
Banyaknya sumberdaya hayati laut di kawasan konservasi mangrove dan Bekantan kota Tarakan merupakan salah satu daerah yang dijadikan sebagai kawasan untuk perlindungan bagi habitat ekosistem perlu di tingkatkan, namun adanya sampah laut di berasal dari buangan masyarakat, sampah dari alam (daun, batang, ranting) yang sudah lapuk dan mengganggu aktifivas dari habitat sehingga dapat mempengaruhi kelangsungan hidup biota akuatik dalam menjaga kawasan tersebut dari kepunahan akibat dampak dari buangan sampah baik dari masyarakat ataupun dampak yang berbahaya yaitu buangan dalam bentuk cairan yang mengganggu aktivitas biota akuatik di daerah KKMB kota Tarakan.

Pentingnya kegiatan coastal clean-up di daerah KKMB memberikan dampak sangat significant kepada masyarakat, karena kegiatan ini merupakan kegiatan internasional yang di galakkan oleh masyarakat dunia pecinta biota dan kawasan ekosistem biota laut perairan di kawasan pesisir pantai dalam menjaga dan melestarikan ekosistem dan spesies secara berkelanjutan dari kepunahan akibat dampak secara tidak langsung dan dampak secara serius terhadap kelangsungan hidup dan keberadaan spesies biota laut di daerah KKMB kota Tarakan.

Coastal clean-up di KKMB kota Tarakan menggunakan system sosialisasi terhadap masyarakat mengenal kegiatan ini yang telah di laksaanakan selama tiga hari yaitu pada hari kamis di tanggal 27 Juni 2019, hari jumat di tanggal 28 Juni 2019 dan hari sabtu di tanggal 29 Juni 2019, dimana kegiatan coastal clean-up di KKMB kota Tarakan dalam rangka menjaga ekosistem habitat ekosistem biota akuatik di KKMB Kota Tarakan. Kegiatan sosialisasi coastal clean-Up pada sesi pertama di lakukan pada hari kamis tanggal 27 Juni 2019 dengan tema pendampingan Observasi Kajian Rona 
Awal Lingkungan Kawasan Konservasi Mangrove dan Bekantan (KKMB) Kota Tarakan dalam mendukung Program Aplikasi Introduksi Coastal Clean-Up Konservasi Habitat Biota Pantai dan Laut Berkelanjutan. Kegiatan sesi kedua sosialisasi mengenai coastal clean-up dilakukan pada hari jumat tanggal 28 Juni 2019 dengan tema pendampingan akis Coastal Clean-Up dan Konservasi Habitat Biota Pantai dan Laut Berkelanjutan Kawasan Konservasi Mangrove dan Bekantan (KKMB) Kota Tarakan. Sesi terakhir yaitu sesi ketiga dilaksanakan sosialisasi mengenai Pendampingan Pemilahan Bahan Terbuang dan Peningkatan Pengetahuan Konservasi Habitat Biota Pantai dan Laut Berkelanjutan Kawasan Konservasi Mangrove dan Bekantan (KKMB) Kota Tarakan.

\section{B. Sosialisasi Coastal Clean-Up di KKMB Kota Tarakan}

Kegiatan pelaksanaan coastal clean up ini terdiri dari dua substansi kegiatan utama yang menjadi satu kesatuan yaitu sosialisasi dan realisasi pelaksanaan (aksi nyata) melalui identifikasi dan pengambilan sampah dilokasi target. Pada pelaksanaan coastal clean up kali ini masyarakat yang berpartisipasi dibatasi sebanyak 75 peserta saja dikarenakan beberapa non teknis membatasi quota tersebut. Distribusi peserta meliputi bapak atau pria dewasa, ibu atau wanita dewasa, pria remaja, wanita remaja dan anak-anak.

Jumlah distribusi sosialisasi peserta coastal clean-up di Kawasan Konservasi Mangrove dan Bekantan Kota Tarakan dan persentase kepedulian dan kesadaran masyarakat terhadap kegiatan coastal cleanup di KKMB Kota Tarakan dapat dilihat pada tabel 1 dan gambar 1 berikut :

Tabel 1. Persentase Keberminatan Peserta terhadap Kegiatan Coastal Clean up dalam kepedulian ekosistem KKMB Kota Tarakan

\begin{tabular}{|c|c|c|c|c|}
\hline No & Identitas Kelamin & Umur & Jumlah (orang) & Persentase \\
\hline 1 & Bapak atau Pria dewasa & $>35$ tahun & 30 & $40 \%$ \\
\hline 2 & Ibu atau wanita dewasa & $>35$ tahun & 8 & $11 \%$ \\
\hline 3 & Pria remaja & $17-35$ tahun & 12 & $16 \%$ \\
\hline 4 & Wanita Remaja & $17-35$ tahun & 18 & $24 \%$ \\
\hline 5 & Anak-anak & $<17$ tahun & 7 & $9 \%$ \\
\hline \multicolumn{3}{|c|}{ TOTAL } & 75 & $100 \%$ \\
\hline
\end{tabular}

Sumber data : Hasil Kegiatan Coastal Clean-Up di KKMB Kota Tarakan (2019)

Berdasarkan tabel 1 di atas menjelaskan bahwa kegiatan coastal clean-up KKMB Kota Tarakan merupakan kegiatan yang menjelaskan mengenai kegiatan yang kepedulian terhadap lingkungan ekosistem biota akuatik dan keberlanjutan kehidupan bioata akuatik di KKMB Kota Tarakan. Kepedulian masyarakat akan kehidupan ekosistem bioata akuatik yang ada di KKMB menunjukkan ada 5 kategori orang yang tertarik terhadap kepedulian dan kelestarian habitat ekosistem biota akuatik yaitu paling banyak yang berminat terhadap kegiatan ini berasal dari golongan bapak/ pria dewasa sebanyak 30 orang dan golongan wanita remaja yang berminat terhadap kelestarian habitat ekosistem keberlangsungan biota akuatik di KKMB Kota Tarakan sebesar 18 orang, sedangkan golongan anak-anak yang masih kurang berminat terhadap kegiatan ini sebesar 7 orang. Kategori Bapak/pria dewasa dan ibu/wanita dewasa memiliki rentang umur sekitar 35 tahun ke atas, Kategori Pria remaja dan wanita remaja, mimiliki rentan umur sekitar 17 tahun sampai dengan 35 
tahun. Sedangkan kategori anak-anak kisaran

umur di bawah 17 tahun (Gambar 1).

\section{KATAGORI UMUR PESERTA KEGIATAN COASTAL CLEAN-UP DI KKMB KOTA TARAKAN}

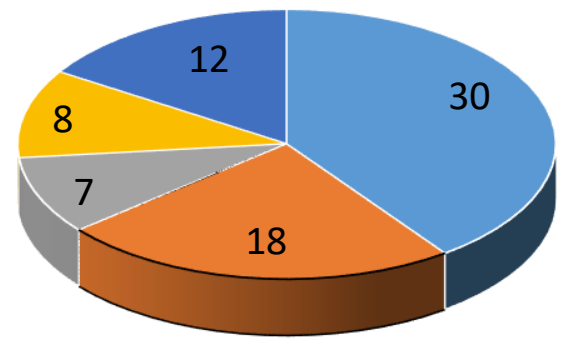

$$
\begin{aligned}
& \text { - Bapak atau Pria dewasa } \\
& \text { - Wanita remaja } \\
& \text { Anak-anak } \\
& \text { - Ibu atau wanita dewasa }
\end{aligned}
$$

Gambar 1. Jumlah Peserta Kegiatan Coastal Clean up

Persentase umur peserta kegiatan coastal clean-up di KKMB Kota Tarakan yang berminat terhadap kegiatan kepedulian dan kelestarian biota akuatik di KKMB terbanyak yaitu dari golongan bapak/ pria dewasa sebanyak 40\%, golongan wanita remaja sebanyak 24\%, golongan pria remaja sebanyak $16 \%$, golongan ibu/wanita dewasa sebanyak $11 \%$ dan golongan anak-anak sebanyak $9 \%$.

KATAGORI UMUR PESERTA KEGIATAN COASTAL CLEAN-UP DI KKMB KOTA TARAKAN

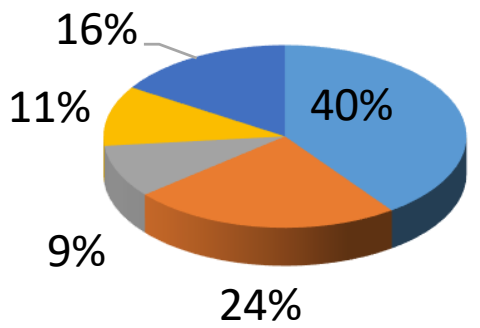

Bapak atau Pria dewasa

Anak-anak

Pria remaja
Wanita remaja

Ibu atau wanita dewasa

Gambar 2. Persentase katagori Umur peserta kegiatan coasatal Clean-Up di KKMB Tarakan

\section{Pelaksanaan Teknis mengenai Coastal Clean-Up}

Pelaksanaan kegiatan coastal clean up di kawasan KKMB Kota Tarakan diperoleh 3 jenis sampah meliputi : sampah berasal dari wisatawan, sampah berasal dari warga sekitar KKMB Kota Tarakan dan sampah dari alam. Distribusi jenis sampah, berat sampah dan persentase jenisnya dapat dilihat pada tabel 2 dan gambar 2 serta gambar 3 berikut ini : 
$\underline{\text { Kampanye Introduksi Kegiatan Internasional Coastal Clean-Up..............(Jimmy Cahyadi dkk) }}$

Tabel 2. Distribusi Jenis, Berat dan Persentase Sampah kegiatan teknis ICC KKMB Tarakan

\begin{tabular}{llcc}
\hline No & \multicolumn{1}{c}{ Jenis Sampah } & Berat Sampah Satuan (kg) & Persentase (\%) \\
\hline 1 & Sampah dari Wisatawan & $18 \mathrm{~kg}$ & $5,5 \%$ \\
2 & Sampah dari Warga Sekitar KKMB & $229,4 \mathrm{~kg}$ & $70,28 \%$ \\
3 & Sampah dari Alam & $79 \mathrm{~kg}$ & $24,2 \%$ \\
\hline \multicolumn{2}{c}{ TOTAL } & $\mathbf{3 2 6 , 4} \mathbf{~ k g}$ & $\mathbf{1 0 0} \%$ \\
\hline
\end{tabular}

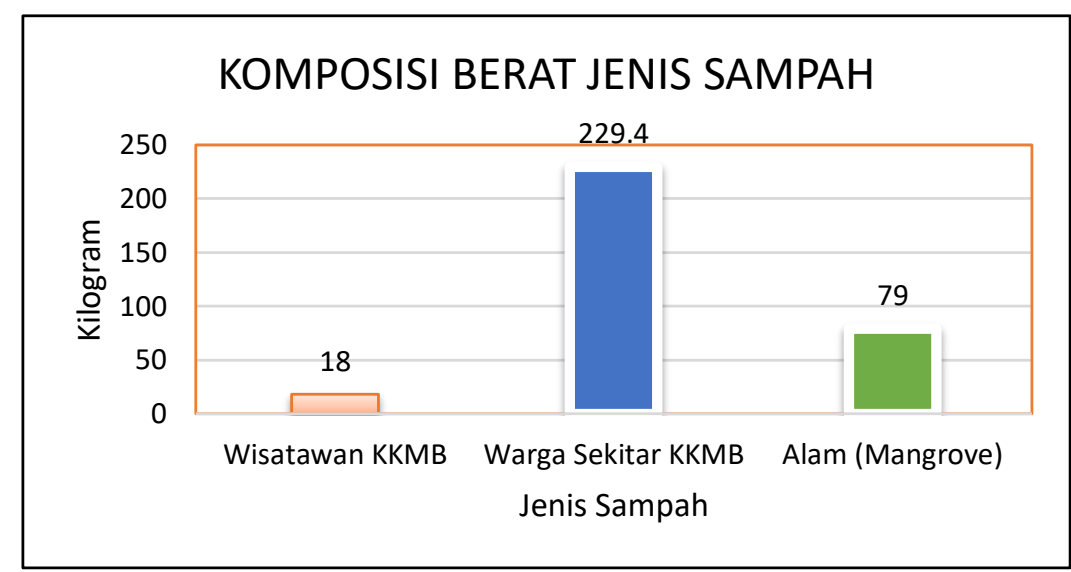

Gambar 2. Komposisi Berat Sampah hasil perhitungan kegiatan ICC di KKMB Tarakan

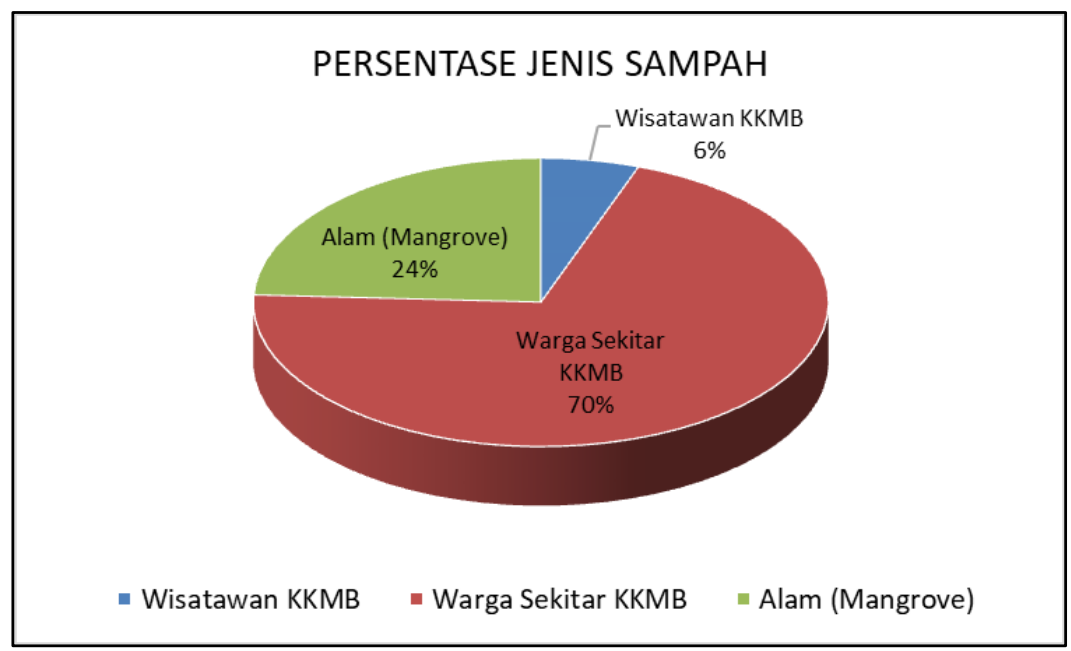

Gambar 3. Persentase Jenis Sampah Kegiatan ICC di KKMB Kota Tarakan

Sampah dari hasil kegiatan bersih pantai dengan titik lokasi tertentu di KKMB Kota Tarakan didapatkan sampah sebanyak $326,4 \mathrm{~kg}$ dengan komposisi distribusi jenis sampah berasal dari wisatawan sebesar $18 \mathrm{~kg}$ dengan persentase sebesar 5,5\% kemudian distribusi jenis sampah berasal dari alam sebesar $79 \mathrm{~kg}$ dengan persentase sebesar
24,2\% dan distribusi jenis sampah berasal dari masyarakat sekitar KKMB Kota Tarakan sebesar 229,4 kg dengan persentase sebesar $70,28 \%$. Banyak masyarakat berminat dan tertarik dengan kegiatan ini karena merupakan salah satu bagian dari kesadaran dalam diri dalam menjaga lingkungan di sekitar di KKMB Kota Tarakan. 
Kegiatan coastal clean-Up di KKMB Kota Tarakan, di liput oleh media TV local yaitu TV-Ku dengan di siarkan secara live di TV local dan berita kegiatan KKMB Kota Tarakan dijadikan sebagai informasi dan pengetahuan bagi masyarakat dunia internasional dan khususnya masyarakat kota Tarakan mengenai coasatal clean-up di kota Tarakan yang memiliki nilai peduli dengan memberikan dukungan penuh terhadap masyarakat dunia internasional berupa coastal clean-up dapat di lihat pada chanel youtube yang di keluarkan secara official di $\mathrm{TV}-\mathrm{Ku}$ pada website https://youtube.be/X7w0JuCL7ww.

\section{Kegiatan Coastal Clean-Up di Tarakan}

Kegiatan coastal clean-up di kota Tarakan sudah di laksanakan oleh para kalangan ahli dari kalangan dosen di Fakultas Perikanan dan Ilmu Kelautan Universitas Borneo Tarakan sebagai salah satu bentuk pengabdian kepada masyarakat. Kegiatan yang sudah di laksanakan coastal clean-up pada tahun 2016 dengan judul Introduksi Program Coasatal Clean-Up Di Pantai Amal Kecamatan Tarakan Timur Kota Tarakan dan pada tahun 2017 dengan judul Kegiatan Introduksi Program Coastal Clean-Up Di Daerah Ekowisata Pantai Binalatung Kota Tarakan.

Hasil kegaitan coastal clean-up dapat di lihat pada tabel 3 di bawah ini sebagai berikut.

Tabel 3. Komparasi hasil penelitian dan pengabdian kepada masyarakat di kota Tarakan

\begin{tabular}{|c|c|c|c|c|c|c|c|}
\hline \multirow[t]{2}{*}{ No } & \multirow[t]{2}{*}{ Jenis Sampah } & \multicolumn{2}{|c|}{$\begin{array}{c}\text { Kegiatan Tahun } 2016 \\
\text { Pantai Amal Lama } \\
\text { Kota Tarakan * }\end{array}$} & \multicolumn{2}{|c|}{$\begin{array}{c}\text { Kegiatan Tahun } 2017 \\
\text { Pantai Binalatung } \\
\text { Kota Tarakan ** }\end{array}$} & \multicolumn{2}{|c|}{$\begin{array}{c}\text { Kegiatan Tahun } 2019 \\
\text { KKMB Kota Tarakan } \\
* * *\end{array}$} \\
\hline & & $\begin{array}{l}\text { Berat } \\
(\mathrm{kg})\end{array}$ & Persen \% & $\begin{array}{l}\text { Berat } \\
(\mathrm{kg})\end{array}$ & Persen $\%$ & $\begin{array}{l}\text { Berat } \\
(\mathrm{kg})\end{array}$ & Persen $\%$ \\
\hline 1 & Alam & 102 & 30.8 & 237 & 56.7 & 79 & 24.2 \\
\hline 2 & Wisatawan & 75.5 & 22.8 & 34.2 & 8.2 & 18 & 5.5 \\
\hline 3 & Masyarakat & 60.5 & 18.3 & - & - & 229.4 & 70.3 \\
\hline 4 & $\begin{array}{l}\text { Budidaya } \\
\text { Rumput Laut }\end{array}$ & 93 & 28.1 & 138 & 33 & - & - \\
\hline 5 & Industri & - & - & 9 & 2.2 & - & - \\
\hline & TOTAL & 303 & 100 & 418.2 & 100 & 326.4 & 100 \\
\hline
\end{tabular}

Pencemaran lingkungan adalah bagian kactor utama peneybab terjadinya penurunan sumberdaya baik berupa keragaman biota laut bahkan populasi spesies biota tersebut yang dapat menyebabkan terjadi perkembangan secara significant penyakit dan pathogen dalam perairan (Bazairi et al 2010 dalam Salim dan Anggoro 2019).

Menurut Salim dan Anggoro (2019) menjelaskan mengenai dampak dari perkembangan pathogen tersebut adalah meningkatnya kerentanan biota terhadap serangan pathogen, sehingga dapat menurunkan populasi serta ancaman kesehatan bagi lingkungan dan manusia. Hal demikian menjadi salah satu factor untuk dilaksanakan kegiatan coastal clean-up.

Kegiatan coastal clean- up dilaksanakan setiap tahun merupakan program tahunan dari masyarakat dunia internasional yang menggerakkan masyrakat relawan dari seluruh penjuru dunia termasuk di daerah kota Tarakan.

Kegiatan coastal clean-up tidak dapat dilaksanakan sekali seumur hidup, dikarenakan kegiatan ini merupakan kegiatan 
rutin tahunan milik masayarakat dunia internasional dimana banyaknya sampah yang berada di perairan setiap tahun yang disebabkan karena pembuangan limbah plastic ataupun limbah masyarakat ke dalam perairan sehingga dapat mengganggu dan menghambat kegiatan reproduksi atapun perkembangbiakan ekosistem habitat spesies tertentu yang menajdikan daerah kawasan coastal clean-up merupakan daerah yang penuh sampah, sehingga dengan adanya kegiatan coastal clean-up ini di kota Tarakan dapat menggerakkan secara humanity agar masyarakat secara sadar dan peduli terhadap ekosistem biota laut agar tidak punah atau endemic di sebabkan karena sampah. Dampak sampah di perairan ada dua yaitu sampah yang tidak dapat terurai dan sampah yang dapat terurai. Sampah terurai di daerah pantai dapat di manfaatkan oleh tanaman lain seperti daun mangrove dan buah mangrove untuk sebagai salah satu produk unsur hara, namun demikian sampah yang berbahaya bagi kelangsungan hidup biota perairan di kawasan ekosistem laut berdampak terhadap kematian ataupun menghambat kegiatan reproduksi atapun kegiatan yang berdampak secara tidak langsung ataupun langsung. Kegiatan coastal clean-up di seluruh kota Tarakan termasuk di daerah KKMB kota Tarakan menjadikan kegiatan yang bermanfaat bagi masyarakat di sekitar KKMB kota Tarakan.

\section{KESIMPULAN}

Pengabdian kepada masyarakat di Kawasan Konservasi Mangrove dan Bekantan Kota Tarakan didapatkan 3 jenis sampah yang telah di pisahkan yaitu sampah dari wisatawan, sampah dari alam, dan sampah dari masyarakat/warga sekitar di KKMB Kota Tarakan. Total keseluruhan sebanyak 326,4 kg dengan komposisi distribusi jenis sampah berasal dari wisatawan sebesar $18 \mathrm{~kg}$ dengan persentase sebesar 5,5 \% kemudian distribusi jenis sampah berasal dari alam sebesar $79 \mathrm{~kg}$ dengan persentase sebesar 24,2\% kemudian distribusi jenis sampah berasal dari masyarakat sekitar KKMB Kota Tarakan sebesar 229,4 kg dengan persentase sebesar 70,28\%. Kepedulian dan kesadaran masyarakat terhadap coastal clean-up di dominasi oleh Bapak atau Pria Dewasa sebesar $40 \%$, di ikuti oleh wanita remaja sebesar $24 \%$ serta pria remaja sekitar $16 \%$, ibu dewasa sekitar $11 \%$ dan anak-anak sekitar $9 \%$.

\section{DAFTAR PUSTAKA}

Atmoko, T. 2010. Beberapa Aspek Bioekologi Bekantan (Nasalis larvatus Wurmb).

Awaluddin, Y.M. 2011. Introduksi Konsep Bersih Pantai (Coastal Clean-Up) Di Pantai Sindangkerta, Kecamatan Cipatujah, Kabupaten Tasikmalaya. Jurnal Harpodon Borneo. Volume 4. No. 2 Tahun 2011.

Bismark, M. Biologi Konservasi Bekantan Nasalis varkatus. SA. Siran, A. Syarief Mukhtar, T. Setyawati (Ed). Departemen Kehutanan. Pusat Penelitian dan Pengembangan Hutan dan Konservasi Alam. Bogor. ISBN 978-979-3145-42-6.

Cahyadi, J dan Salim, G., 2017. Penerapan sistem program Introduksi coastal clean up di Ekowisata Pantai Binalatung Kota Tarakan. Jurnal pengabdian masyarakat Borneo (JPMB) Volume 2 nomor 2 Desember 2018 (E-ISSN:2579-9797 dan PISSN: 2615-4323) e-journal : http://jurnal.borneo.ac.id/index.php/j $\mathrm{pmb} / \mathrm{index}$

Handaka, AA., I. Riyantini, M.Y. Awaluddin. 2007. Kepedulian Masyarakat Terhadap pencemaran di 
$\underline{\text { Kampanye Introduksi Kegiatan Internasional Coastal Clean-Up..............(Jimmy Cahyadi dkk) }}$

wilayah pesisir Pameungpeuk

Kabupaten Garut. Jurnal Akuatika. FPIK Unpad.

Ohkura, Y. and Kojima, A., 2007. International Coastal Clean-Up Campaign Coordinated by JEAN in Japan Present state and future prospects. The $2^{\text {nd }}$ NOWPAP Workshop on Marine Litter. 28-29 March.

Ocean Concervancy. 2011. Tracking trash 25 years of action for the Ocean. Organisation Report. 43pp.

Salim, G dan Febrinaldy R. 2017. Introduksi Program Coastal Clean-Up di Pantai Amal Kecamatan Tarakan Timur Kota Tarakan. Laporan Akhir Kegiatan Pengabdian kepada Masyarakat yang berasal dari DIPA
Universitas Borneo Tarakan. 42 Halaman. Tidak di publikasikan.

Salim, G dan Febrinaldy R. 2018. Introduksi dan Penerapan Sistem Program Coastal Clean-Up. Jurnal Pengabdian Masyarakat Borneo (JPMB). Universitas Borneo Tarakan. Volume 2 Nomer 1. Halaman 39-43. (EISSN:2579-9797 dan P-ISSN: 26154323)

http://jurnal.borneo.ac.id/index.php/j pmb/index

Salim dan Anggoro. 2019. Domestikasi Udang Prospek Masa Depan Sumber Pangan Dari Laut. ISBN 978-623209-369-0. Nomor Pencatatan HKI 000140201 pada tanggal 30 April 2019. Penerbit Deepublish (CV Budi Utama). Yogyakarta. 183 Halaman. 